\title{
Screening and Isolation of Protease Producing Bacteria from Rhizospheric Soil of Apple Orchards from Shimla District (HP), India
}

\author{
Kumari Manorma ${ }^{1}$, Shweta Sharma ${ }^{2}$, Himani Singla ${ }^{3}$, \\ Kirti Kaundal $^{1}$ and Mohinder Kaur ${ }^{1}$
}

\author{
${ }^{1}$ Department of Basic Science (Microbiology), Dr. Yashwant Singh Parmar University of \\ Horticulture and Forestry, Nauni, Solan-173230 (HP), India \\ ${ }^{2}$ Directorate of Mushroom Research, Chambaghat, Solan-173213 (HP), India \\ ${ }^{3}$ Department of Basic Sciences (Microbiology) UHF, Nauni-Solan, HP, India \\ *Corresponding author
}

\begin{tabular}{|c|c|}
\hline & A B S T R A C T \\
\hline Keywords & \multirow{5}{*}{$\begin{array}{l}\text { The objective of present study was to screen and isolate protease producing } \\
\text { bacteria from soil samples collected from rhizospheric soil of apple orchard from } \\
\text { Kotkhai of Shimla District. Collected soil samples were serially diluted and } 0.1 \mathrm{ml} \\
\text { of sample was spread on skim milk agar plates at } 37^{0} \mathrm{C} \text { for } 48 \text { hrs. Out of fifteen, } \\
\text { six bacterial colonies from rhizospheric soil samples showed clear zone around the } \\
\text { colony indicating protease activity. Among these, two isolates i.e. } \mathrm{KK}_{3} \text { and } \mathrm{KK}_{4} \\
\text { produced highest protease activity and was identified as Pseudomonas } \mathrm{Sp} \text {. by } \\
\text { physiological, morphological and biochemical test, the isolated protease producing } \\
\text { bacteria also having antifungal activity against different plant pathogenic fungi. } \\
\text { The above results indicate that these bacterial isolates can be used as a biocontrol } \\
\text { agent against different phytopathogens. }\end{array}$} \\
\hline Protease activity, & \\
\hline $\begin{array}{l}\text { Rhizosphere soil, } \\
\text { Apple orchard, } \\
\text { Pseudomonas sp., } \\
\text { Skim milk. }\end{array}$ & \\
\hline Article Info & \\
\hline $\begin{array}{l}\text { Accepted: } \\
\text { 04 April } 2017 \\
\text { Available Online: } \\
10 \text { May } 2017\end{array}$ & \\
\hline
\end{tabular}

\section{Introduction}

To produce environmental eco-friendly products and product out puts chemical process are being replaced by enzymes like proteases (Abebe et al., 2014). The production of enzymes is central to the modern biotechnology of industrial and agricultural fields. The technology for producing and using commercially important enzyme products combines the discipline of microbiology, genetics, biochemistry and engineering. Enzymes are biocatalysts produced by living cells to bring about specific biochemical reaction generally forming parts of the metabolic processes of cells (Mohammad et al., 2013). Proteases which include proteinases, peptidases or proteolytic enzymes break peptide bonds between amino acids of proteins. They use a molecule of water for this and are thus classified as hydrolases. Proteases are of two types exopeptidases and endo-peptidases (Grewal et al., 2010).

Proteases play a crucial role in numerous pathological processes. Microbial proteases have been proposed as virulence factors in a variety of diseases caused by microorganisms. The virulence of Pseudomonas aeruginosa is 
multifactorial, but it is partly determined by exoproducts such as alkaline protease and elastase, which are responsible for the damage of tissues by degrading elastin, collagen and proteoglycans. These enzymes have been also shown to degrade proteins that function in host defense in vivo (Sakata et al., 1993).

In bacteria, serine and metallo-proteases are the principal classes of proteases found in several species such as Bacillus subtilis, $B$. amyloliquefaciens, Pseudomonas sp., Lysobacter enzymogenes and Escherichia coli (Fujishige et al., 1992).

Identification and characterization of microbial proteases are prerequisites for understanding their role in the pathogenesis of infectious diseases as well as to improve their application in biotechnology (Lantz and Ciborowski, 1994). Bacterial Proteases are preferred as they grow rapidly, needless space, can be easily maintained and are accessible for genetic manipulations (Odu et al., 2012).

In the present study, soil samples were collected from different area of Khotkhai for screening of Protease producing bacteria and study of their morphological and physiological characters.

\section{Materials and Methods}

\section{Source of sample collection}

Soil samples were collected from rhizosphere of apple orchard at Rauni (Kotkhai) of Shimla district. Soil samples were taken from five different plant rhizosphere and mixed to make composite sample. Each soil sample was collected around $10 \mathrm{~cm}$ apart and from a depth of $1 \frac{1}{2}-2$ feet. Rhizosphere soil samples along with root pieces were collected and stored in plastic bags at $4^{0} \mathrm{C}$ temperature until further processing.

\section{Isolation of proteolytic bacteria}

The techniques used for isolation of bacteria were serial dilution and spread plate method. Ten gram of rhizoplane soil sample was shaken vigorously in $90 \mathrm{ml}$ of sterile water blank in $150 \mathrm{ml}$ flask as a stock for further dilutions. Serial dilution $\left(10^{-1}\right.$ to $\left.10^{-6}\right)$ of each soil sample was carried out $0.1 \mathrm{ml}$ of each aliquot was spread on skim milk agar (1\%) plate at temperature $28^{\circ} \mathrm{C}$ for 48 hour. The zone of hydrolysis was noted for each sample. The colony showing highest zone of inhibition was selected for further study. The colony was grown on nutrient agar plate repeatedly and preserved on nutrient agar slant at $4^{\circ} \mathrm{C}$. Based on the morphological and biochemical tests the bacterial isolate was identified (Sneath et al., 1986).

\section{Identification of bacteria}

The identification of bacteria was carried out by morphological and physiological studies i.e. staining including Gram staining. Cultural characterization on agar plates like colony morphology that is shape, size, margin, elevation, opacity, texture and pigmentation and also growth in different temperatures that is $4^{\circ} \mathrm{C}, 25^{\circ} \mathrm{C}, 37^{\circ} \mathrm{C}$ and $41^{\circ} \mathrm{C}$ and biochemical test includes catalase test, oxidase test, carbohydrate fermentation test, Starch hydrolysis test, Gelatin liquification, denitrification test, Tween 80 hydrolysis and Lecithinase test (Aneja).

\section{Quantitative assay of protein}

The total protein content of the samples were determined by Lowry's method (Lowry and Bessey, 1946). The protein standard used was Bovine Serum Albumin (BSA) (.1mg/ml).

\section{Preparation of casein solution}

Casein was used as substrate. It was prepared from alkali soluble casein which was 
dissolved in $10 \mathrm{ml}$ distilled water. The insoluble portion was dissolved by addition of the alkali. The $\mathrm{pH}$ was adjusted to 8.0 with $0.1 \mathrm{M}$ sodium hydroxide.

\section{Crude enzyme preparation}

The protease producing bacterial colony was inoculated in Nutrient broth medium. It was incubated at $28^{\circ} \mathrm{C}$ for 72 hours. The culture broth was subjected to centrifugation at $12,000 \mathrm{rpm}$ for 20 minutes to remove unwanted particles. The supernatant was used as crude enzyme preparation for further studies.

\section{Qualitative assay (Proteolytic activity)}

All bacterial species were screened out for proteolytic activity by well plate assay method on skim milk agar plates. $100 \mu \mathrm{l}$ of 72 $\mathrm{h}$ old cell free culture supernatant of each bacterial species was added to each well already cut on skim milk agar plate in which $1 \%$ of separately autoclaved skim milk is added to nutrient agar medium. Plates were incubated at $28 \pm 2^{\circ} \mathrm{C}$ for $24-48 \mathrm{~h}$. Proteolytic activity was expressed in terms of $\mathrm{mm}$ diameter of clear zones produced around the well (Kaur et al., 1989).

\section{Quantitative method (Protease enzyme assay)}

To study proteoloytic activity, supernatant was used as enzyme source. 1\%casein in 0.1 $\mathrm{M}$ phosphate buffer and $\mathrm{pH}$ 7.0) was used as substrate. $1 \mathrm{ml}$ enzyme and substrate was incubated at $50^{\circ} \mathrm{C}$ for $60 \mathrm{~min}$. To stop the reaction $3 \mathrm{ml}$ trichloroacetic acid was used. One unit of protease activity was defined as the increase of 0.1 unit optical density at $1 \mathrm{hr}$ incubation period. Then it was centrifuged at $5000 \mathrm{rpm}$ for $15 \mathrm{~min}$. From this $0.5 \mathrm{ml}$ of supernatant was taken, to this $2.5 \mathrm{ml}$ of $0.5 \mathrm{M}$ sodium carbonate was added, mixed well and incubated $20 \mathrm{~min}$. Then it was added with $0.5 \mathrm{ml}$ of folin phenol reagent and the absorbance was read at $660 \mathrm{~nm}$ using Spectrophotometer (Bharat et al., 2014). The amount of protease produced was estimated and expressed in microgram of tyrosine released under standard assay conditions. Based on the tyrosine released the protease activity.

\section{Antifungal activity}

Antifungal activity of each test isolate of Pseudomonas sp. was checked by standard well/bit plate assay method (Vincent, 1947). Fresh culture bits (10 mm dia) of 5 days old indicator fungi were cut with the help of sterile well borer and placed on the one side of prepoured malt extract agar (MEA) plates with the help of sterile inoculating needle. On the other side of plates, $10 \mathrm{~mm}$ well was cut with the help of sterile cork borer. $100 \mu \mathrm{l}$ of $72 \mathrm{~h}$ old cell free culture supernatant of each test bacterial isolates was added to each well $(10 \mathrm{~mm})$. For control culture bit of indicator fungi kept in the centre of MEA plate and incubated at $28 \pm 2^{\circ} \mathrm{C}$ for 4 days. Antifungal activity expressed in terms of $\mathrm{mm}$ diameter of mycelial growth and that in turn expressed as per cent inhibition of fungal mycelia growth as calculating from equation:

$$
\begin{array}{ll}
\begin{array}{l}
\text { Percent } \\
\text { inhibition }(\% \mathrm{I})
\end{array}=\frac{\mathrm{C}-\mathrm{T}}{\mathrm{C}} \times 100 \\
\mathrm{C} \quad \mathrm{g} & \text { growth of mycelium in control } \\
\mathrm{T} \quad \mathrm{growth} \text { of mycelium in } \\
\text { treatment }
\end{array}
$$

\section{Results and Discussion}

In the present study various isolates were screened for protease activity on the casein agar plates in terms of $\mathrm{mm}$ diameter of zone of hydrolysis. Six bacterial isolates showed proteolytic activity. Protease activity was 
observed in the range of 11 to $23 \mathrm{~mm}$ from the zone of hydrolysis observed on agar surface mentioned in table 1 . Among these six isolates, maximum protease activity was shown by $\mathrm{KK}_{3}$ i.e. $23 \mathrm{~mm}$. The protease producer was identified as genus Pseudomonas sp. a gram negative bacteria. The identification was done on the basis of their morphological, physiological and biochemical characterization. The isolate $\mathrm{KK}_{3}$ which shown maximum protease production also having antifungal activity in terms of $\mathrm{mm}$ diameter i.e. 40.0 and percent inhibition in terms of \% I i.e. $42.85 \%$ against fungal pathogen Pythium ultimum. For further study the strain showing largest zone of hydrolysis was considered and designated as $\mathrm{KK}_{3}$ were preserved and maintained at $4^{0} \mathrm{C}$ by repeated sub culturing.

Table.1 Zone of inhibition (mm)

\begin{tabular}{|c|c|c|}
\hline Sr.No & Isolates & Zone of Inhibition(mm) \\
\hline 1. & $\mathbf{K k}_{\mathbf{1}}$ & 16 \\
\hline 2. & $\mathbf{K k}_{\mathbf{2}}$ & 15 \\
\hline 3. & $\mathbf{K k}_{\mathbf{3}}$ & 23 \\
\hline 4. & $\mathbf{K k}_{\mathbf{4}}$ & 19 \\
\hline 5. & $\mathbf{K k r}_{\mathbf{1}}$ & 11 \\
\hline 6. & $\mathbf{K k r}_{\mathbf{2}}$ & 13 \\
\hline
\end{tabular}

Table.2 Colony morphology on agar plates

\begin{tabular}{|c|c|c|c|c|c|c|c|}
\hline S.No. & Isolates & Sites & Shape & Elevation & Edge & Opacity & Pigment \\
\hline 1 & $\mathbf{K k}_{\mathbf{1}}$ & Kotkhai & Circular & Flat & Entire & Transparent & Yellowish \\
\hline 2 & $\mathbf{K k}_{\mathbf{2}}$ & Kotkhai & Circular & Flat & Entire & Transparent & Yellowish \\
\hline 3 & $\mathbf{K k}_{\mathbf{3}}$ & Kotkhai & Circular & Raised & Entire & Transparent & Yellowish \\
\hline 4 & $\mathbf{K k}_{\mathbf{4}}$ & Kotkhai & Iregular & Raised & Entire & Transparent & Yellowish \\
\hline 5 & $\mathbf{K k r}_{\mathbf{1}}$ & Kotkhai & Circular & Raised & Entire & Transparent & Yellowish \\
\hline 6 & $\mathbf{K k r}_{\mathbf{2}}$ & Kotkhai & Circular & Raised & Entire & Transparent & Yellowish \\
\hline
\end{tabular}


Table.3 Physiological and biochemical characteristics

\begin{tabular}{|c|c|c|c|c|c|c|c|c|c|c|c|c|c|}
\hline $\begin{array}{l}\text { Sr. } \\
\text { No. }\end{array}$ & Isolates & $\begin{array}{c}\text { Gelatin } \\
\text { Liquification }\end{array}$ & Denitrification & Catalase & $\begin{array}{l}\text { Tween } 80 \\
\text { hydrolysis }\end{array}$ & $\begin{array}{c}\text { Gram } \\
\text { staining }\end{array}$ & $\begin{array}{c}\text { Oxidase } \\
\text { test }\end{array}$ & $4^{0} \mathrm{C}$ & $25^{\circ} \mathrm{C}$ & $37^{0} \mathrm{C}$ & $42^{0} \mathrm{C}$ & $\begin{array}{c}\text { Starch } \\
\text { hydrolysis }\end{array}$ & Lecitinase \\
\hline 1 & $\mathbf{K k}_{\mathbf{1}}$ & + & + & + & - & - & + & + & + & + & - & - & + \\
\hline 2 & $\mathbf{K k}_{\mathbf{2}}$ & + & + & + & - & - & + & + & + & + & - & + & + \\
\hline 3 & $\mathbf{K k}_{\mathbf{3}}$ & - & + & + & - & - & + & + & + & + & - & - & - \\
\hline 4 & $\mathbf{K k}_{\mathbf{4}}$ & + & + & + & - & - & + & + & + & + & - & - & - \\
\hline 5 & $\mathbf{K k r}_{1}$ & - & - & + & - & - & + & + & + & + & - & - & - \\
\hline 6 & $\mathrm{Kkr}_{2}$ & + & + & + & - & - & + & + & + & + & - & - & - \\
\hline
\end{tabular}

(+) sign indicates positive test

(-) sign indicates negative test

Table.4 Antifungal activity by Protease producing Pseudomonas isolate $\mathrm{KK}_{3}$ against Pythium ultimum

\begin{tabular}{|c|c|c|c|}
\hline \multirow{2}{*}{$\begin{array}{c}\text { Sr. } \\
\text { No. }\end{array}$} & \multirow{2}{*}{ Isolate } & \multicolumn{2}{|c|}{ Percent inhibition of fungal pathogen } \\
\cline { 3 - 4 } & & \multicolumn{2}{|c|}{ Pythium ultimum (Control=70mm) } \\
\cline { 3 - 4 } & & mm diameter & \% Inhibition \\
\hline 1. & $\mathrm{KK}_{3}$ & 40 & 42.85 \\
\hline
\end{tabular}


Figure.1 Isolated colony of Pseudomonas isolate $\mathrm{KK}_{3}$ on nutrient agar plate

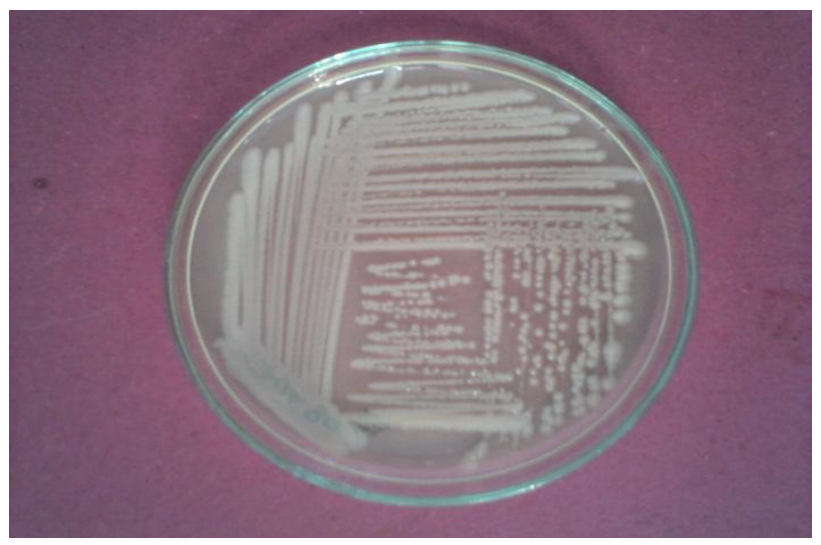

Figure.2 Zone of inhibition on skim milk agar plate by isolate $\mathrm{KK}_{3}$

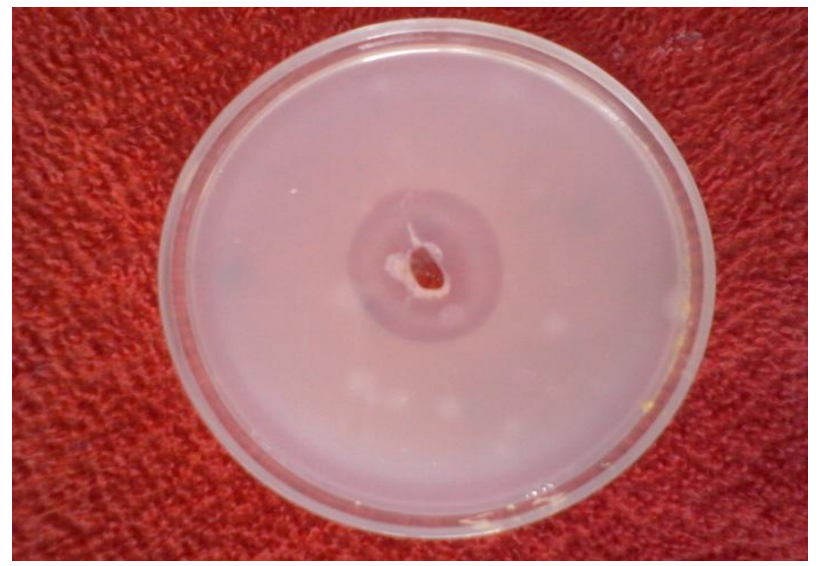

Figure.3 Antifungal activity showed by Pseudomonas isolate $\mathrm{KK}_{3}$ against Pythium ultimum

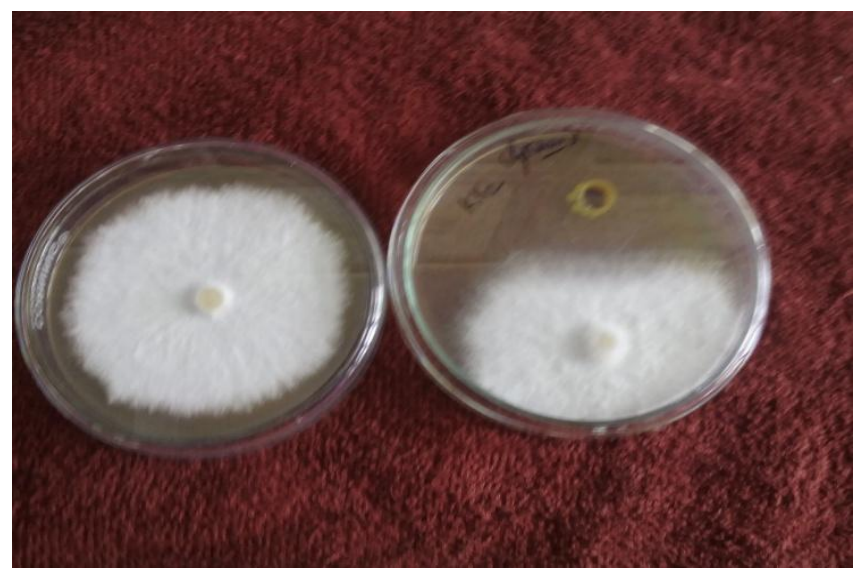


It was found that the rhizospheric soil of apple orchard at Kotkhai of Shimla District shows the presence of protease producers. The bacteria were screened and identified on the basis of their morphological, physiological and biochemical characteristics as Pseudomonas sp. Qualitative and qualitative estimation were also done. Antifungal activity of Pseudomonas isolates against pathogenic fungi was also done. These bacteria can be very useful in agricultural fields due to their antagonistic properties against phytopathogens and can be used as a biocontrol agent. Further experiments were carried out to enhance enzyme production and their purification for further studies.

\section{Acknowledgement}

The authors are highly thankful to the department of Basic Science (Microbiology) and department of Plant Pathology of Dr Y S Parmar University of Horticulture and Forestry, Nauni-Solan (HP)-173230, India to carry out the present work.

\section{References}

Abebe, B., Sago, A., Admasu, G., Getache, H., Kassaand, P., Amsaya, M. 2014. Isolation, optimization and characterization of protease producing bacteria from soil and water in Gondar town, Northwest Ethiopia. Int. J. Bacteriol. Virol. Immunol., 1(3): 020024.

Bharat, P., Pandeya, A., Gurung, S., Bista, G., Kandel, S., Kande, R.C. and Magar, R.T. 2014. Screening and optimization of extra cellular protease from bacteria isolated from sewage. European J. Biotechnol. Biosci., 2(1): 46-49.
Fujishige, A., Smith, K.R., Silen, J.L. and Agard, D.A. 1992. Correct folding of a-lytic protease is required for its extracellular secretion from Escherichia coli. J. Cell Biol., 118: 33-42.

Grewal, S. and Mutha, P. 2010. Enzyme technology. Published by Agrobios (India): $145-148$.

Kaur, M., Gupta, M., Tripatathi, K.A.K. and Gupta, K.G. 1989. Lytic effect of Pseudomonas aeruginosa elastase on gram positive and gram negative bacteria. Indian J. Microbiol., 34: 855-859.

Lantz, M.S., Ciborowski, P. 1994. Zymographic techniques for detection and characterization of microbial proteases. Methods in Enzymol., 235: 563-594.

Lowry, O.H. and Bessey, O.A. 1946. Protein measurement with the folin-phenols reagent. J. Biol. Chem., 163: 633.

Mohammad, B.D. and Mastan, S.A. 2013. Isolation, characterization and screening of enzyme producing bacteria from different soil samples. Int. J. Pharma. Biosci., 4(3): 813-824.

Odu, N.N., Akujobi, C.O. 2012. Protease production capabilities of Micrococcus Luteus and Bacillus species isolated from abattoir environment. J. Microbiol. Res., 2(5): 127-132.

Sakata, K., Yajima, H., Tanaka, K., Sakamoto, Y., Yamamoto, K., Yoshida, A. and Dohs, Y. 1993. Erythromycin inhibits the production of elastase by Pseudomonas aeruginosa without affecting its proliferation in vitro. American Rev. Respiratory Dis., 148: 10611065.

Sneath, H.A.P., Halt, G.J. 1986. eds. Bergey,s Manual of Systematic Bacteriology, Vol 2.

Vincent, J.M. 1947. Distribution of fungal hyphae in presence of certain inhibitors. Nature, 150: $158-850$.

\section{How to cite this article:}

Kumari Manorma, Shweta Sharma, Himani Singla, Kirti Kaundal and Mohinder Kaur. 2017. Screening and Isolation of Protease Producing Bacteria from Rhizospheric Soil of Apple Orchards from Shimla District (HP). Int.J.Curr.Microbiol.App.Sci. 6(5): 249-255.

doi: http://dx.doi.org/10.20546/ijcmas.2017.605.030 